\title{
Severity of Impulsivity and Aggression at a 12-Month Follow-Up Among Male Heroin Dependent Patients
}

\author{
Cuneyt Evren', Alkin Yilmaz², Yesim Can², Muge Bozkurt², Bilge Evren², Gokhan Umut ${ }^{2}$
}

ÖZET:

Eroin bağımlısı erkek hastaların 12 aylık izleminde dürtüsellik ve agresyon şiddeti

Amaç: Bu çalışmanın amacı hastaneden taburcu olduktan 12 ay sonra halen idame tedavisi olarak buprenorfin/nalokson kullanan hastalar ile depreşen hastaların dürtüsellik ve agresyon puanlarındaki değişimi incelemekti.

Yöntem: Ardışık olarak kliniğe yatışı yapılan 78 erkek eroin bağımlısı hastadan 52 'si taburculuktan 12 ay sonra yüz yüze görüşme ile değerlendirildi. Hastalara hem başlangıçta hem de 12 ayın sonunda Barrat Dürtüsellik Ölçeği ve Buss-Perry Agresyon Ölçeği uygulandı.

Sonuçlar: Yatarak tedavi gören 52 eroin bağımlısı hastanın \%44.23'ünün (n=23) 12 aylık izlemde depreşme yaşadığı görüldü. Sosyodemografik veriler gruplar arasında fark göstermedi. Depreşen grupta (DG) başlangıçta sözel agresyon düzeyi idame grubuna (IG) göre daha düşükken, izlem sonunda fiziksel agresyon ve dürtüsellik puanları DG'da İ'na göre daha yüksekti. On iki ayın sonunda IG'de agresyon (düşmanlık) ve dürtüsellik (motor ve plansızlık) şiddeti daha düşükken, DG'da agresyon (motor ve sözel agresyon) ve dürtüsellik (dikkat ve plansızlık) şiddeti daha yüksekti. Lojistik regresyon modellerinde başlangıç değerlendirmesinde depreşmeyi düşük sözel agresyon ve yüksek motor dürtüsellik belirlerken, izlemde öfke ve motor dürtüselliğin belirlediği görüldü.

Sonuç: Motor dürtüsellik depreşmeyle ilişkili önemli bir boyut gibi gözükmektedir. 12 aylık izlem sırasında agresyon ve dürtüsellik puanları DG'de yükselirken, IG'de düşmüştür. İG'da saptanan daha iyi sonuçlar hastaların değişen yaşam biçimleri ve yaşam kalitesi, işlevsellik, kişiler arası ilişkiler, fiziksel ve mental sağlık alanlarındaki iyileşmelerle ilişkili olabilir.

Anahtar sözcükler: eroin bağımlılığı, buprenorfin, agresyon, dürtüsellik, depreşme

Klinik Psikofarmakoloji Bulteni 2014;24(2):158-67

\section{ABSTRACT:}

Severity of impulsivity and aggression at a 12-month follow-up among male heroin dependent patients

Objective: The aim of this study was to evaluate the changes in impulsivity and aggression scores among male heroin dependent patients using buprenorphine/ naloxone as a maintenance treatment and those who relapsed within 12 months of their discharge from the hospital.

Method: Among 78 consecutively admitted male heroin dependents, 52 were available and examined by face-to-face interview 12 months after discharge from the hospital. Patients were investigated by using the Barratt Impulsiveness Scale, version 11 (BIS-11) and the Buss-Perry Aggression Questionnaire (AQ) both at baseline and at the end of 12 months.

Results: Among 52 heroin dependent patients, $44.23 \%$ $(n=23)$ were considered to have relapsed during the 12-month follow-up. Sociodemographic variables did not differ between the groups. The mean score of verbal aggression was lower in the relapse group (RG) than in the maintenance group (MG) at baseline, whereas physical aggression and impulsivity scores were higher in the RG than the MG at the end. In the MG aggression (hostility) and impulsivity (motor and non-planning) were lower at the end of 12 months, whereas aggression (motor and verbal aggression) and impulsivity (attentional and non-planning) were higher in the RG. In logistic regression models, low verbal aggression and high motor impulsiveness evaluated at baseline predicted a relapse, whereas anger and motor impulsiveness predicted a relapse in the evaluation after 12 months.

Conclusion: Motor impulsiveness seems to be an important dimension that may be related to relapse. While aggression and impulsivity scores increased in the RG during the 12-month follow-up, they decreased in the MG. These positive results found in the MG may be related to the patients' change in life style, improvements in quality of life, functioning, interpersonal relationships and both physical and mental health.

Keywords: heroin dependence, buprenorphine, aggression, impulsivity, relapse

Bulletin of Clinical Psychopharmacology 2014;24(2):158-67
${ }^{1}$ Assoc. Prof., ${ }^{2}$ M.D., Bakirkoy Training and Research Hospital for Psychiatry Neurology and Neurosurgery, Alcohol and Drug Research, Treatment and Training Center (AMATEM), Istanbul - Turkey ${ }^{3}$ M.D., Baltalimani Training and Research Hospital for Muskuloskeletal Disorders, Department of Psychiatry, Istanbul - Turkey

Address reprint requests to: Dr. Cuneyt Evren, Icadiye Cad. Mentes Sok. Selçuk Apt. 1/17 Kuzguncuk 34674 Üsküdar, Istanbul - Türkiye

Phone: +90-212-409-1515/2111

Fax: +90-212-660-0026

E-mail address: cuneytevren@yahoo.com

Date of submission:

September 22, 2013

Date of acceptance: December 18, 2013

Declaration of interest:

C.E., A.Y., Y.C., M.B., B.E., G.U.: The authors reported no conflict of interest related to this article. 


\section{INTRODUCTION}

Heroin dependence is a major cause of morbidity and mortality and a worldwide problem that substantially increases HIV transmission all around the world, including Turkey. Abstinence-oriented symptomatic treatment has been the most commonly offered treatment option in Turkey until the end of 2009. Starting in 2010, a buprenorphine/ naloxone combination was approved by the Turkish Ministry of Health for use in heroin dependent patients as a maintenance treatment ${ }^{1}$. The central problem in the treatment of heroin dependency is high rates of relapse after periods of forced or selfimposed abstinence ${ }^{2}$. Relapse is a multi-factorial phenomenon and most likely results from a combination of various factors ${ }^{3}$. Variables involved in relapse include the individual characteristics of the patient, the drug and environmental reinforcements ${ }^{3,4}$.

Impulsivity has been related to risk taking, lack of planning, and quick decision-making ${ }^{5}$. Definitions of impulsivity suggest that such behaviors tend to be committed without forethought or conscious judgment, and are characterized by acting on the spur of the moment, the inability to focus on a specific task, and a lack of adequate planning ${ }^{6,7}$. There is accumulating evidence from preclinical laboratory animal and clinical studies indicating that impulsive behavior might be causally linked to several distinct processes in drug addiction including the onset, maintenance, related problems and relapse $\mathrm{e}^{8-12}$.

High relative co-morbidity is observed between substance use disorders and Axis I and Axis II psychiatric disorders from the impulse control spectrum, i.e. antisocial personality disorder ${ }^{13}$ Moeller et al. ${ }^{14}$ have found that the most marked difference in characteristics between substance users and control subjects is a high level of impulsivity in substance users. It has also been suggested that impulsivity is a temperamental risk factor for substance use ${ }^{15}$ and might be a fundamental mechanism in both the onset of excessive substance use ${ }^{16}$ and relapse ${ }^{17}$. Impulsivity has also been found to be a high-risk factor for early substance use, and related to the severity of drug abuse and treatment retention ${ }^{18,19}$. Impulsivity may also serve as a moderator of the relationship between substance-use behavior and substance-use outcomes, such as substance userelated problems ${ }^{20-22}$. Impulsivity might contribute significantly to the risk of suicide attempts in substance-dependent patients ${ }^{23}$, may interrupt their outpatient or inpatient treatment ${ }^{24}$ and may mediate the effects of substance use on aggression $^{25}$.

Aggressiveness has been defined as an overt behavior, which intends to inflict damage on another individual. Although aggressive acts are state phenomena, trait aggressiveness refers to a disposition to behave aggressively across various situations and over repeated occasions ${ }^{26}$. A strong relationship of substance use disorders with aggression has been demonstrated ${ }^{27}$. The association between substance abuse and aggressiveness is undoubtedly complex, but a series of investigations with first graders revealed that boys who were identified by teachers/peers as more aggressive were more likely to use drugs in the future $^{28}$. Early aggressive behavior was found to be predictive of later substance abuse ${ }^{29}$. In addition, conduct disorder symptoms have been observed to begin some years before regular drug use $\mathrm{u}^{30}$. In conclusion, there is some evidence suggesting that aggressive personality traits may predate addictive behavior. Aggression is considered as a distal risk factor predisposing to the development of suicidal behavior in substance dependent individuals ${ }^{31,32}$.

Impulsivity and aggressiveness (a tendency towards aggression) are not the same constructs. According to "behavioral theory", an impulse is triggered by an environmental or inner stimulus; it stems from an alteration to homeostatic balance, and action is the direct consequence of that. Aggressiveness is a planned, premeditated act, whereas impulsive 'acting-outs' are unplanned, overwhelming and inadequate outbursts of rage and anger, which do not help anyone to reach any actual goal ${ }^{33}$. Nevertheless, impulsivity and aggression are usually related to each other ${ }^{34}$. Patients with substance use disorders are frequently 
associated with impulsivity that may underlie elevated levels in life-threatening types of behavior, including aggression ${ }^{35}$. Impulsive aggression is characterized by an inability to regulate affect as well as aggressive impulses and is highly comorbid with other mental disorders including substance abuse $^{36}$. Consistent with this, prisoners with substance abuse had both high impulsivity and aggressiveness when compared to prisoners without substance abuse ${ }^{37}$. Studies also suggest that impulsive aggression may be associated with a certain subtype of substance abuse (i.e. early onset) ${ }^{36}$.

The existing literature suggests that both impulsivity ${ }^{12,16}$ and aggression ${ }^{33}$ may be multidimensional constructs and individual differences may exist across the different dimensions of these constructs, which may be related to different patterns and severities of substance use. Also both impulsivity $^{12}$ and aggression ${ }^{33}$ might be causally linked to the relapsing nature of drug use. Opioid agonists are promising agents for the treatment of aggressive behaviours in non-addicted patients ${ }^{33}$. A buprenorphine naloxone combination, which was approved by the Turkish Ministry of Health in December 2009, is the only agent that is used for maintenance treatment in Turkey. Therefore, the aim of this study was to evaluate the changes in impulsivity and aggression scores among heroin dependent patients who were still using buprenorphine as a maintenance treatment and those who had relapsed at a 12-month follow-up.

\section{METHODS}

\section{Settings and Sample}

The study was conducted in Bakırköy Research and Training Hospital for Psychiatry, Neurology and Neurosurgery, Alcohol and Drug Research Treatment and Training Center (AMATEM) in Istanbul. The study was approved by the Ethical Committee of the hospital and the written consent of the patients was obtained after the study protocol was thoroughly explained.

Maintenance treatment was started in heroin dependent inpatients and the stabilization phase ended after one to two weeks. Baseline interviews with the patients were done at the end of this phase. After being discharged from the hospital, they were advised to participate in the Outpatient Treatment Program (OTP) once a week for at least one year, whereas they were obligated to come to the policlinic every month to get the buprenorphine prescribed.

\section{Baseline Evaluation}

Baseline evaluation was conducted between February 2011 and July 2011. One hundred consecutively admitted heroin-dependent inpatients without a history of any other substance dependence were considered for participation in the study. All participants fit the DSM-IV diagnostic criteria for heroin dependence. The exclusion criteria were illiteracy, mental retardation, cognitive impairment or comorbid psychotic disorders. Thus, five patients were excluded due to illiteracy and three patients due to cognitive deficits, who received a score below 25 in the Standardized Mini Mental State Examination ${ }^{38}$. Although none of the patients refused to participate in the study, 14 patients were excluded because they left some parts of the assessment scales blank, did not give the forms back or left the treatment program prematurely, i.e. before completing the forms. Therefore, from 100 eligible heroindependent inpatients, 78 were enrolled in the study. Baseline interviews with the study group were conducted after the stabilization period, i.e. 1-2 weeks after the last day of heroin use.

\section{Follow-up Evaluation}

Follow-up evaluation was conducted between February 2012 and July 2012. Twelve months after they were enrolled in the study, each of the 78 participants was contacted by phone to invite them to the clinic for an interview. Sixty-two (79.5\%) patients could be reached by phone. All patients were invited to the clinic for a face-to-face interview. Relapse was assessed by interviewing the patient and family members and/or documents from the 
OTP when possible. Relapsing patients were offered immediate inpatient treatment despite the waiting list if they came to the clinic for an interview. Nevertheless, face-to-face interviews were achieved only with $52(66.7 \%)$ patients. The remaining 10 patients could not or did not want to come to the clinic for several reasons, whereas all of them reported that they had relapsed. Only the patients that were eligible for a face-to-face interview at the end of the follow-up were included in the present study.

Although within the context of the current study, relapse was defined as the use of heroin even once within the 12-month follow-up period, those who relapsed during the 12 months were consuming heroin regularly at least in the amount of their prior use.

\section{Measures}

All patients were assessed by using a semistructured socio-demographic form. The diagnosis of heroin dependence in each participating patient was based on a clinical examination and a screening interview based on the Structured Clinical Interview for the DSM-IV (SCID-I) ${ }^{39}$, Turkish version ${ }^{40}$, conducted by a trained interviewer (CE) at baseline. Among 52 subjects interviewed face-to-face after 12 months, $23(44.23 \%)$ were considered as relapsed and $29(55.77 \%)$ were considered as patients in buprenorphine maintenance treatment. During interviews at the end of 12 months, a sociodemographic form which was specially designed for evaluating variables that might be related to relapse and the scales mentioned below were used.

\section{The Barratt Impulsiveness Scale, version 11 (BIS-11)}

BIS- $11^{6}$ provides a measure of trait-impulsivity. The BIS-11 is a self-reported questionnaire that asks participants to rate how often a series of statements applies to them. Cumulative scores range from 30 (low in trait-impulsivity) to 120 (high in traitimpulsivity). The BIS-11 has been shown to be reliable in both clinical and community samples, with Cronbach's alpha coefficients ranging from 0.79 to $0.83^{6}$. The BIS- 11 has been validated in general psychiatric and normal populations as well as a group of male inmates from a maximum security prison unit ${ }^{6}$. The BIS-11 is structured to assess longterm patterns of behavior and has been used to assess trait levels of impulsivity across a variety of populations, including substance-dependent individuals $^{14,41,42}$. A final revised version was produced in 1995 (version 11) comprising three factors: motor (behavior), attentional (cognitive) and non-planning. Evidence for these factors was found in samples of undergraduates, psychiatric inpatients and adult male prisoners ${ }^{6}$. The BIS-11 has been adapted to Turkish settings ${ }^{43}$. In the present study, Cronbach's alpha was 0.55, 0.65, and 0.71 respectively.

\section{Buss-Perry Aggression Questionnaire (AQ)}

Trait aggression was measured by the total score of the AQ and scores of the subscales including physical aggression, verbal aggression, anger, and hostility (PA, VA, A, H). Evidence for the scale's construct validity is available elsewhere ${ }^{44}$. The AQ has been adapted to Turkish settings ${ }^{45}$.

\section{Statistical Methods}

The statistical package SPSS 11.5 for Windows was used for all the analyses. Categorical variables were compared by means of chi-square statistics. We used the Student t test to compare the groups on continuous variables, since these variables were normally distributed. Logistic Regression models (Enter) were performed to evaluate variables that predict relapse. In both of these models, independent variables were subscale scores of BIS11 and AQ. Since this study is cross-sectional, results of these regression analyses should be interpreted with precaution. The term 'predictors' in present study is used as a more general term to classify all independent variables in regression analyses, rather than describing a causal relationship. 


\section{RESULTS}

Among 78 heroin dependent inpatients, 52 (66.7\%) were available for interview at the end of one year. Twenty-three $(44.23 \%)$ of these patients were considered to be relapsed during the previous year, whereas $29(55.77 \%)$ were still in the maintenance treatment. Among those who relapsed, the mean time to relapse was $3.52 \pm 2.84$ months
(Minimum=1, Maximum=12). Mean age, duration of education, age at first substance use, marital and employment status did not differ between the relapse and remission groups (Table 1).

Mean score of verbal aggression was lower in the relapse group (RG) than the maintenance group (MG) at baseline, whereas physical aggression and impulsivity scores were higher in the RG than the MG at the end (Table 2).

Table 1: Sociodemographic variables

\begin{tabular}{|c|c|c|c|c|c|c|c|}
\hline & \multicolumn{2}{|c|}{$\begin{array}{l}\text { The Maintenance } \\
\text { Group }\end{array}$} & \multicolumn{2}{|c|}{$\begin{array}{l}\text { The Relapse } \\
\text { Group }\end{array}$} & \multirow[b]{2}{*}{$\chi^{2}$} & \multirow[b]{2}{*}{ df } & \multirow[b]{2}{*}{$\mathbf{P}$} \\
\hline & $\mathbf{n}=\mathbf{2 9}$ & $\%$ & $\mathbf{n}=\mathbf{2 3}$ & $\%$ & & & \\
\hline Age (mean \pm sd) & 31.31 & 9.51 & 30.83 & 6.65 & $\mathrm{t}=0.207$ & & 0.837 \\
\hline Duration of education (mean \pm sd) & 9.38 & 3.04 & 8.57 & 2.41 & $t=1.049$ & & 0.299 \\
\hline Age at first substance use (mean \pm sd) & 20.38 & 6.41 & 19.13 & 4.19 & $\mathrm{t}=0.807$ & & 0.423 \\
\hline Marital status & & & & & 1.408 & 2 & 0.494 \\
\hline Married & 12 & 41.4 & 8 & 34.8 & & & \\
\hline Divorced, Widowed, Separated & 2 & 6.9 & 4 & 17.4 & & & \\
\hline Single & 15 & 51.7 & 11 & 47.8 & & & \\
\hline Employment status & & & & & 4.336 & 3 & 0.362 \\
\hline Unemployed & 14 & 48.3 & 13 & 56.5 & & & \\
\hline Employed & 7 & 24.1 & 3 & 13.0 & & & \\
\hline Part time employed & 5 & 17.2 & 7 & 30.4 & & & \\
\hline Retired & 3 & 10.3 & 0 & 0.0 & & & \\
\hline
\end{tabular}

Table 2: A comparison of scale scores of patients in remission and patients that relapsed at baseline and at the end of the 12 month follow-up

\begin{tabular}{|c|c|c|c|c|c|c|}
\hline & \multicolumn{2}{|c|}{$\begin{array}{l}\text { The Maintenance Group } \\
\qquad(n=29)\end{array}$} & \multicolumn{2}{|c|}{$\begin{array}{l}\text { The Relapse Group } \\
\qquad(n=23)\end{array}$} & \multirow[b]{2}{*}{$\mathbf{t}$} & \multirow[b]{2}{*}{$\mathbf{p}$} \\
\hline & mean & sd & mean & sd & & \\
\hline \multicolumn{7}{|l|}{ Baseline } \\
\hline Physical aggression & 12.69 & 6.96 & 11.48 & 5.63 & 0.677 & 0.502 \\
\hline Verbal aggression & 10.05 & 3.45 & 7.70 & 3.56 & 2.428 & $0.019^{*}$ \\
\hline Anger & 12.03 & 6.87 & 11.52 & 5.99 & 0.282 & 0.779 \\
\hline Hostility & 13.31 & 8.35 & 12.44 & 6.65 & 0.410 & 0.684 \\
\hline Buss Perry Aggression Scale & 48.10 & 21.63 & 43.13 & 17.02 & 0.902 & 0.371 \\
\hline Attentional & 16.62 & 4.43 & 16.78 & 3.02 & -0.150 & 0.881 \\
\hline Motor & 22.38 & 4.92 & 23.78 & 3.98 & -1.110 & 0.272 \\
\hline Non-planning & 28.66 & 4.13 & 28.74 & 4.89 & -0.067 & 0.947 \\
\hline Barratt Impulsiveness Scale -11 & 67.66 & 11.37 & 69.30 & 8.92 & -0.570 & 0.571 \\
\hline \multicolumn{7}{|l|}{ Follow-up } \\
\hline Physical aggression & 12.59 & 5.49 & 16.35 & 5.42 & -2.468 & $0.017^{*}$ \\
\hline Verbal aggression & 8.69 & 3.04 & 9.61 & 4.61 & -0.864 & 0.392 \\
\hline Anger & 10.69 & 7.19 & 12.52 & 6.76 & -0.937 & 0.353 \\
\hline Hostility & 10.03 & 6.85 & 11.78 & 5.49 & -0.996 & 0.324 \\
\hline Buss Perry Aggression Scale & 42.00 & 19.01 & 50.26 & 17.72 & -1.603 & 0.115 \\
\hline Attentional & 16.04 & 3.27 & 18.48 & 3.09 & -2.744 & $0.008^{*}$ \\
\hline Motor & 19.10 & 4.13 & 24.83 & 3.82 & -5.130 & $<0.001^{*}$ \\
\hline Non-planning & 25.72 & 5.18 & 30.87 & 4.19 & -3.862 & $<0.001^{*}$ \\
\hline Barratt Impulsiveness Scale -11 & 60.86 & 11.34 & 74.17 & 8.79 & -4.630 & $<0.001^{*}$ \\
\hline
\end{tabular}


In the MG aggression (hostility) and impulsivity (motor and non-planning) were lower at the end of 12 months, whereas aggression (motor and verbal aggression) and impulsivity (attentional and nonplanning) were higher in the RG (Table 3).
In Logistic regression models low verbal aggression and high motor impulsiveness predicted relapse according to baseline scores, whereas according to follow-up scores anger and motor impulsiveness predicted relapse (Table 4).

Table 3: A comparison of scale scores between baseline and at the end of the 12-month follow-up in patients in remission and patients that relapsed

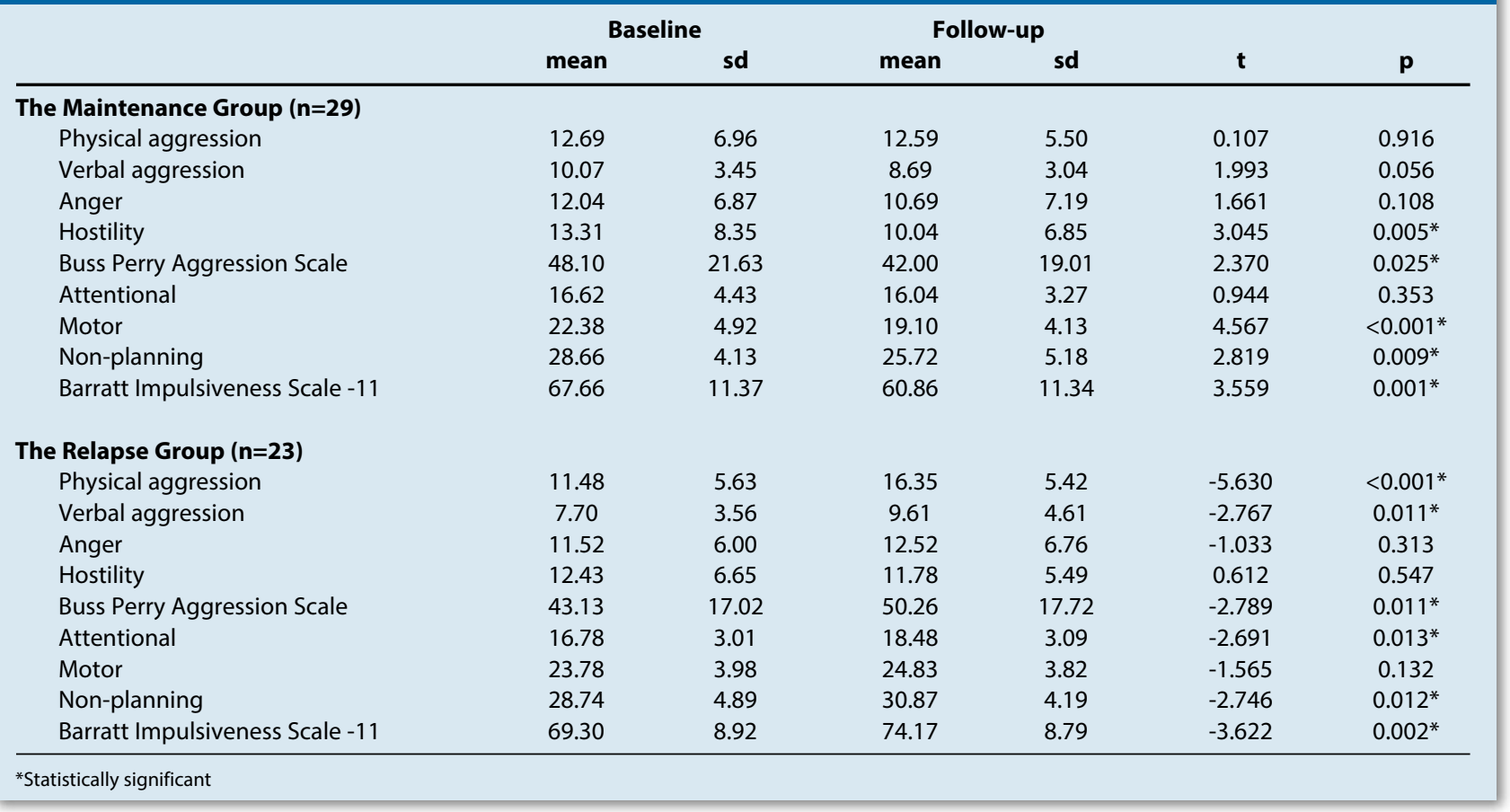

Table 4: Logistic regression (Enter) when relapse status is the dependent variable and subscales of the AQ and BIS-11 are independent variables

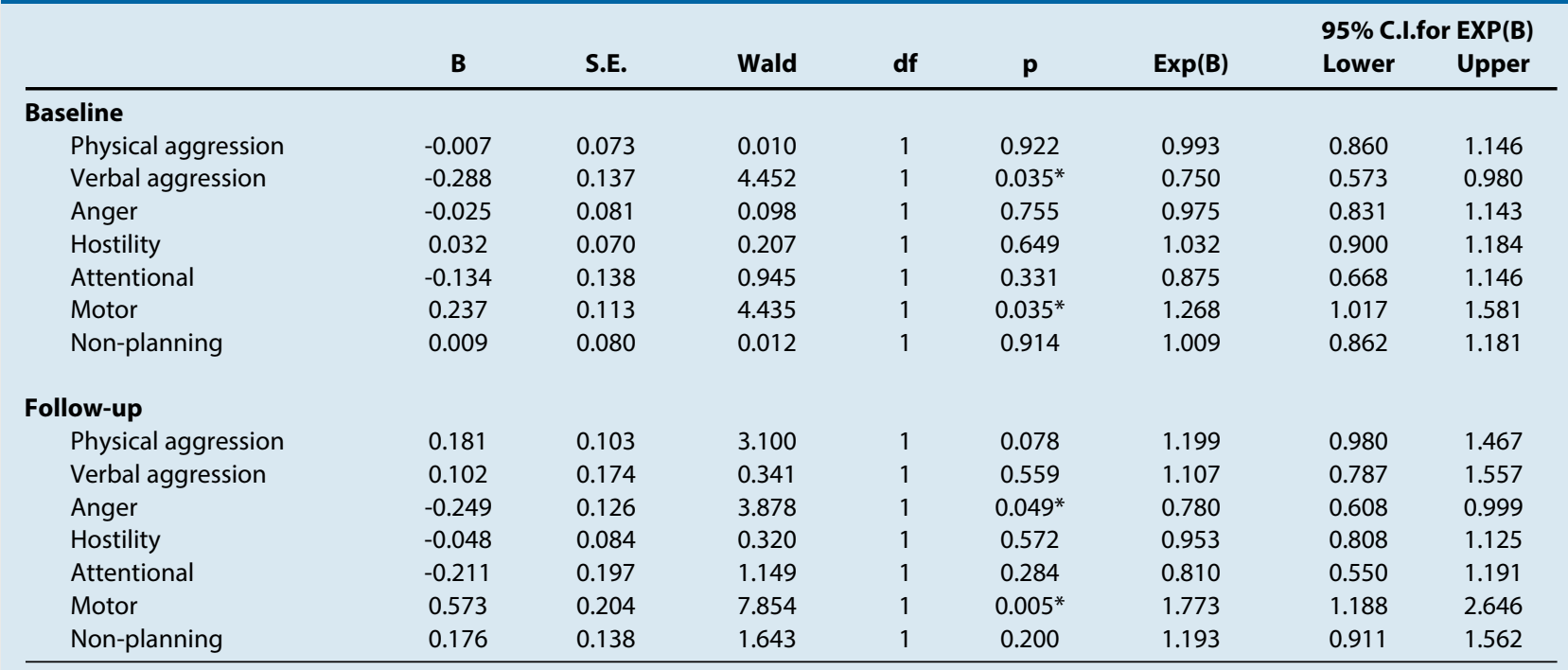

Nagelkerke $\mathrm{R}^{2}$ for baseline was 0.26 and for follow-up was 0.63 , *Statistically significant 


\section{DISCUSSION}

The important finding of the present study was that, while aggression and impulsivity scores increased in the RG during the 12 month follow-up, they decreased in the MG. Earlier studies have showed that maintenance treatment, such as with methadone, reduces criminal and disruptive behaviours ${ }^{46}$. A recent study suggested that buprenorphine seemed to produce even better results than methadonein patients with prominently violent-suicidal behaviors ${ }^{47}$. Given the effectiveness of opioids as anti-aggressive and anti-impulsive drugs in heroin addicts and the involvement of the opioid system in modulating aggressiveness and impulsiveness, buprenorphine indeed may be the optimal drug for this form of use because of its kinetics and potency ${ }^{33}$. Nevertheless, these positive results in the MG may be related with patients' changed life style, improvements in the quality of life, functioning, interpersonal relationships and both physical and mental health ${ }^{48}$.

From a neuropsychological point of view, heroin use has both short- and long-term consequences. In particular, impulse control dysfunction and negative affective states have been reported ${ }^{49,50}$. The continuous intake of this substance increases levels of impulsivity and aggressiveness that return to baseline (pre-heroin) levels throughout abstinence. In heroin-dependent subjects, impulsivity and aggressiveness therefore become more intense as a result of chronic heroin exposure, rather than being a vulnerability trait ${ }^{51}$. Heroin use may be related to aggression and impulsivity particularly during withdrawal periods. Heroin-dependent subjects may prefer this substance because of the selfmedication dynamics, i.e. for its positive effects in managing pre-existing rage and aggressiveness ${ }^{52}$. Hence, it may be the case that individuals who become heroin users are more likely to show aggressiveness not because of the drug itself, but because of a pre-existing premorbid aggressive disposition, leading them to form ties selectively with heroin ${ }^{53}$. Nevertheless, although some have suggested that aggressiveness seems to be related more to premorbid personalities than to addiction itself $^{54}$, aggressiveness usually is supported by impulsiveness, and may mirror the severity of opiate intoxication ${ }^{55}$. A recent review suggested that the aggressive behavior of heroin addicts is probably different from that of other kinds of mentally ill patients, non-opiate substance abusers and the general population, and seems to be specifically related to the degree of chronic intoxication ${ }^{33}$.

In the present study, impulsivity scores did not differ between the groups at baseline, whereas they were higher in the RG than the MG at follow-up. The BIS- $11^{6}$ measures three subtypes of impulsiveness: cognitive (attentional) impulsiveness (inattention and cognitive instability), motor impulsiveness (motor disinhibition), and non-planning impulsiveness (lack of self-control and intolerance of cognitive complexity). Interestingly motor impulsivity decreased in the MG, whereas attentional and non-planning impulsivity increased in the RG. Also motor impulsiveness seems to be an important dimension that may be related to relapse according to both baseline and follow-up scores. In a recent study, impulsive personality was found to play a role in the onset of heroin use and, among the three factors, the motor factor appeared to have the largest effect on the age of onset of drug use ${ }^{56}$. The motor factor was defined as "acting on the spur of the moment" by Patton et al. ${ }^{6}$. Substance dependent individuals are often impaired on tasks measuring motor impulsivity ${ }^{57}$, which is manifested by poor inhibitory control of pre-potent responses ${ }^{58}$. Also impulsivity has been discussed as a potential mediator of the relationship between craving and relapse $^{59}$. In response to stress or environmental cues, an individual with substance abuse could use the substance in a rapid unplanned action without regard to the consequences. Once the substance has been used, cravings and withdrawal may lead to continued use or dependence ${ }^{60}$.

Nevertheless, the present study had several limitations. First of all, this study is cross-sectional, thus the causal relationship between relapse and variables such as aggression and impulsivity and factors that may mediate these relationships cannot be determined. Secondly, all measures used in the present study were self-reported. Nevertheless, we 
considered that the patients' self-reports and information from relatives would be valid and the patients were personally interviewed and were well known by the same interviewer (A.Y.). Moreover, impulsivity may directly interfere with the completion of the questionnaires themselves, such that the impulsive subject may give less consideration to responses than the non-impulsive subject. Introspective ratings assume that individuals have sufficient insight to rate their personality accurately. Another limitation of the present study was that all the patients were male. Male and female heroin-dependent patients may differ in their impulsive and aggressive behavior; i.e. females have been found to be more hostile than males ${ }^{61}$. Finally, the study group was restricted to a treatment-seeking population, and it was not

\section{References:}

1. T.C. Ministry of Health General Directorate of Pharmaceuticals and Pharmacy, November 23, 2009 Circular, No 079,661(2009/74) and October 14, 2010 Circular No. 070,068 (2010/72). (Turkish)

2. Bossert JM, Ghitza UE, Lu L, Epstein DH, Shaham Y. Neurobiology of relapse to heroin and cocaine seeking: an update and clinical implications. Eur J Pharmacol 2005;526(1-3):36-50. [CrossRef]

3. Bottlender M, Soyka M. Impact of craving on alcohol relapse during, and 12 months following, outpatient treatment. Alcohol Alcohol 2004;39(4):357-61. [CrossRef]

4. de Bruijn C, Korzec A, Koerselman F, van Den Brink W Craving and withdrawal as core symptoms of alcohol dependence. J Nerv Ment Dis 2004;192(7):494-502. [CrossRef]

5. Eysenck SB, Eysenck HJ. The place of impulsiveness in a dimensional system of personality description. Br J Soc Clin Psychol 1977;16(1):57-68. [CrossRef]

6. Patton JH, Stanford M S, Barratt ES. Factor structure of the Barratt Impulsiveness Scale. J Clin Psychol 1995;51(6):76874. [CrossRef]

7. Moeller FG, Barratt FS, Dougherty DM, Schmitz JM, Swann AC. Psychiatric aspects of impulsivity. Am J Psychiatry 2001;158(11):1783-93. [CrossRef]

8. Kisa C, Yildirim SG, Goka E. Impulsivity and mental disorders. Turk Psikiyatri Derg 2005;16(1):46-54.

9. Bjork JM, Hommer DW, Grant SJ, Danube C. Impulsivity in abstinent alcohol-dependent patients: relation to control subjects and type 1-/type 2-like traits. Alcohol 2004;34(23):133-50. [CrossRef] possible to generalize the present findings to nontreatment groups.

At a minimum, the findings of the present study may suggest that motor impulsiveness is an important dimension that may be related to relapse among heroin dependent patients. Also maintenance treatment of these patients with buprenorphine seems to improve impulsivity and aggression. Although causal relationships were not evaluated in the present study, since both heroin and buprenorphine are opioid receptor agonists, it may be possible to suggest that these improved results in the MG might be related to changes in the patients' life style, improvements in quality of life, functioning, interpersonal relationships and both physical and mental health rather than a direct effect of buprenorphine.

10. Brady KT, Myrick H, McElroy S. The relationship between substance use disorders, impulse control disorders, and pathological aggression. Am J Addict 1998;7(3):221-30. [CrossRef]

11. Vitaro F, Ferland F, Jacques C, Ladouceur R. Gambling, substance use, and impulsivity during adolescence. Psychol Addict Behav 1998(3);12:185-94. [CrossRef]

12. Pattij T, De Vries TJ. The role of impulsivity in relapse vulnerability. Curr Opin Neurobiol 2013 23(4):700-5. [CrossRef]

13. Verheul R, van den BrinkW. The role of personality pathology in the aetiology and treatment of substance use disorders. Curr Opin Psychiatry 2000;13(2):163-9. [CrossRef]

14. Moeller FG, Dougherty DM, Barratt ES, Oderine V, Mathias CW, Harper RA, et al. Increased impulsivity in cocaine dependent subjects independent of antisocial personality disorder and aggression. Drug Alcohol Depend 2002;68(1): 105-11. [CrossRef]

15. Acton GS. Measurement of impulsivity in a hierarchical model of personality traits: implications for substance use. Subst Use Misuse 2003;38(1):67-83. [CrossRef]

16. Lane SD, Cherek DR, Rhoades HM, Pietras CJ, Tcheremissine OV. Relationships among laboratory and psychometric measures of impulsivity: implications in substance abuse and dependence. Addict Disord Their Treat 2003;2(2):33-40. [CrossRef]

17. Miller L. Predicting relapse and recovery in alcoholism and addiction: neuropsychology, personality, and cognitive style. J Subst Abuse Treat 1991;8(4):277-91. [CrossRef] 
18. Tarter RE, Kirisci L, Mezzich A, Cornelius JK, Pajer K, Vanyukov $\mathrm{M}$, et al. Neurobehavioral disinhibition in childhood predicts early age at onset of substance use disorder. Am J Psychiatry 2003;160(6):1078-85. [CrossRef]

19. Patkar AA, Thornton CC, Mannelli P, Hill KP, Gottheil E, Vergare $\mathrm{MJ}$, et al. Comparison of pretreatment characteristics and treatment outcomes for alcohol- , cocaine-, and multisubstance-dependent patients. J Addict Dis 2004;23:93-109. [CrossRef]

20. Simons JS. Differential prediction of alcohol use and problems: the role of biopsychological and socialenvironmental variables. Am J Drug Alcohol Abuse 2003;29(4):861-79. [CrossRef]

21. Simons JS, Carey KB. Risk and vulnerability for marijuana use problems: the role of affect dysregulation. Psychol Addict Behav 2002;16(1):72-5. [CrossRef]

22. Wills TA, Sandy JM, Yaeger AM. Moderators of the relation between substance use level and problems: test of a self-regulation model in middle adolescence. J Abnorm Psychology 2002;111(1):3-21. [CrossRef]

23. Koller G, Preuss UW, Bottlender M, Wenzel K, Soyka M. Impulsivity and aggression as predictors of suicide attempts in alcoholics. Eur Arch Psychiatry Clin Neurosci 2002;252(4):155-60. [CrossRef]

24. Murray HW, Parkar AA, Mannelli P, DeMaria P, Desai AM, Vergare MJ. Relationship of aggression, sensation seeking, and impulsivity, with severity of cocain use. Addict Disord Their Treat 2003;2(4):113-21. [CrossRef]

25. Fulwiler C, Eckstine J, Kalsy S. Impulsive-aggressive traits, serotonin function, and alcohol-enhanced aggression. J Clin Pharmacol 2005;45(1):94-100. [CrossRef]

26. Tremblay PF, Dozois DJA. Another perspective on trait aggressiveness: overlap with early maladaptive schemas. Pers Individ Differ 2009(6);46:569-74. [CrossRef]

27. Hofvander B, Stahlberg O, Nydén A, Wentz E, degl'Innocenti A, Billstedt E, et al. Life History of Aggression scores are predicted by childhood hyperactivity, conduct disorder, adult substance abuse, and low cooperativeness in adult psychiatric patients. Psychiatry Res 2011;185(1-2):280-5. [CrossRef]

28. Kellam SG, Ialongo N, Brown H, Laudolff J, Mirsky A Anthony B, et al. Attention problems in first grade and shy and aggressive behaviours as ante cedents to late heavy or inhibited substance use. NIDA Res Monogr 1989;95:368-9.

29. Moffitt TE. Adolescence-limited and life-course-persistent antisocial behavior: a developmental taxonomy. Psychol Rev 1993;100(4):674-701. [CrossRef]

30. Young SE, Mikulich SK, Goodwin MB, Hardy J, Martin CL, Zoccolillo MS, Crowley TJ. Treated delinquent boys' substance use: onset, pattern, relationship to conduct and mood disorders. Drug Alcohol Depend 1995;37(2):149-62. [CrossRef]

31. Roy A. Characteristics of opiate dependent patients who attempt suicide. J Clin Psychiatry 2002;63(5);403-7. [CrossRef]
32. Tremeau F, Darreye A, Staner L, Corrêa H, Weibel H, Khidichian F, et al. Suicidality in opioid-dependent subjects. Am J Addict 2008;17(3):187-94. [CrossRef]

33. Bacciardi S, Maremmani AG, Rovai L, Rugani F, Lamanna F, Dell'Osso L, et al. Aggressive behaviour and heroin addiction. Heroin Addict Relat Clin Probl 2012;14(4):81-94.

34. Derefinko K, DeWall CN, Metze AV, Walsh EC, Lynam DR. Do different facets of impulsivity predict different types of aggression? Aggress Behav 2011;37(3):223-33. [CrossRef]

35. Roozen HG, van der Kroft P, van Marle HJ, Franken IH. The impact of craving and impulsivity on aggression in detoxified cocaine-dependent patients. J Subst Abuse Treat 2011;40(4):414-18. [CrossRef]

36. Seo D, Patrick CJ, Kennealy PJ. Role of serotonin and dopamine system interactions in the neurobiology of impulsive aggression and its comorbidity with other clinical disorders. Aggress Violent Behav 2008;13(5):383-95. [CrossRef]

37. Cuomo C, Sarchiapone M, Giannantonio MD, Mancini M, Roy A. Aggression, impulsivity, personality traits, and childhood trauma of prisoners with substance abuse and addiction. Am J Drug Alcohol Abuse 2008;34(3):339-45. [CrossRef]

38. Gungen C, Ertan T, Eker E, Yasar R, Engin F. Reliability and validity of the standardized Mini Mental State Examination in the diagnosis of mild dementia in Turkish population Turk Psikiyatri Derg 2002;13(4):273-81.

39. First MB, Spitzer RL, Gibbon M, Williams JBW. Stuructured Clinical Interview for DSM-IV Axis I Disorders (SCID-I), Clinical Version. Washington D.C. and London. American Psychiatric Press, Inc, 1997.

40. Corapcioglu A, Aydemir O, Yildiz M, Esen A, Koroglu E. Structured Clinical Interview for DSM-IV Axis I Disorders (SCID-I), Clinical Version. Hekimler Yayin Birligi, Ankara, 1999.

41. Mitchell SH. Measures of impulsivity in cigarette smokers and non-smokers. Psychopharmacology 1999;146(4):455-64. [CrossRef]

42. Allen TJ, Moeller FG, Rhoades HM, Cherek DR. Impulsivity and history of drug dependence. Drug Alcohol Depend 1998;50(2):137-45. [CrossRef]

43. Gulec H, Tamam L, Gulec MY, Turhan M, Karakus G, Zengin $\mathrm{M}$, et al. Psychometric properties of the Turkish version of the barrattimpulsiveness scale-11. KlinikPsikofarmakoloji BülteniBulletin of Clinical Psychopharmacology 2008;18(4):251-58.

44. Buss AH, Perry M. The aggression questionnaire. J Pers Soc Psychol 1992;63(3):452-9. [CrossRef]

45. Evren C, Cinar O, Celik S, Evren B. Reliability and validity of turkish version the buss-perry's aggression questionnaire in male alcohol dependent inpatients. Düșünen Adam Psikiyatri ve Nörolojik Bilimler Dergisi-Dusunen Adam Journal of Psychiatry and Neurological Science 2011;24(4):283-95. [CrossRef] 
46. Fugelstad A, Agren G, Romelsjö A. Changes in mortality, arrests, and hospitalizations in nonvoluntarily treated heroin addicts in relation to methadone treatment. Subst Use Misuse 1998;33(14):2803-17. [CrossRef]

47. Maremmani AG, Rovai L, Pani PP, Pacini M, Lamanna F, Rugani F, et al. Do methadone and buprenorphine have the same impact on psychopathological symptoms of heroin addicts? Ann Gen Psychiatry 2011;10:17. [CrossRef]

48. Martin PR, Reid Finlayson AJ. Pharmacopsychosocial treatment of opioid dependence: harm reduction, palliation, or simply good medical practice? Düşünen Adam Psikiyatri ve Nörolojik Bilimler Dergisi-Dusunen Adam The Journal of Psychiatry and Neurological Sciences 2012;25(1):1-7. [CrossRef]

49. Koob GF, Le Moal M. Drug abuse: hedonic homeostatic dysregulation. Science 1997;278(5335):52-8. [CrossRef]

50. Swann AC, Bjork JM, Moeller FG, Dougherty DM. Two models of impulsivity: relationship to personality traits and psychopathology. Biol Psychiatry 2002;51(12):988-94. [CrossRef]

51. Schippers MC, Binnekade R, Schoffelmeer AN, Pattij T, De Vries TJ. Unidirectional relationship between heroin self-administration and impulsive decision-making in rats. Psychopharmacology (Berl) 2012;219(2):443-52. [CrossRef]

52. Aharonovich E, Nguyen HT, Nunes EV. Anger and depressive states among treatment-seeking drug abusers: testing the psychopharmacological specificity hypothesis. Am J Addict 2001;10(4):327-34. [CrossRef]

53. Hoaken PN, Stewart SH. Drugs of abuse and the elicitation of human aggressive behavior. Addict Behav 2003;28(9):153354. [CrossRef]
54. Gerra G, Zaimovic A, Moi G, Bussandri M, Bubici C, Mossini M, et al. Aggressive responding in abstinent heroin addicts: neuroendocrine and personality correlates. Prog Neuropsychopharmacol Biol Psychiatry 2004;28(1):129-39. [CrossRef]

55. Maremmani I, Pani PP, Canoniero S, Pacini M, Perugi G, RihmerZ, et al. Is the bipolar spectrum the psychopathological substrate of suicidality in heroin addicts? Psychopathology 2007;40(5):269-77. [CrossRef]

56. Li T, Du J, Yu S, Jiang H, Fu Y, Wang D, et al. Pathways to age of onset of heroin use: a structural model approach exploring the relationship of the COMT gene, impulsivity and childhood trauma. PLoS One 2012;7(11):e48735. [CrossRef]

57. Verdejo-Garcia A, Perez-Garcia M. Profile of executive deficits in cocaine and heroin polysubstance users: common and differential effects on separate executive components. Psychopharmacology 2007;190(4):517-30. [CrossRef]

58. Dougherty DM, Bjork JM, Harper RA, Marsh DM, Moeller FG, Mathias CW, et al. Behavioral impulsivity paradigms: a comparison in hospitalized adolescents with disruptive behavior disorders. J Child Psychol Psychiatry 2003;44(8):1145-57. [CrossRef]

59. Tracy JI. Assessing the relationship between craving and relapse. Drug Alcohol Rev 1994;13(1):71-7. [CrossRef]

60. Jentsch JD, Taylor JR. Impulsivity resulting from frontostriatal dysfunction in drug abuse: implications for the control of behavior by reward-related stimuli. Psychopharmacology (Berl) 1999;146(4):373-90. [CrossRef]

61. Petry NM, Bickel WK. Gender differences in hostility of opioid-dependent outpatients: role in early treatment termination. Drug Alcohol Depend 2000;58(1-2):27-33. [CrossRef] 